\title{
Top1 and Top2 promote replication fork arrest at a programmed pause site
}

\author{
Mélanie V. Larcher and Philippe Pasero \\ Institut de Génétique Humaine, Centre National de la Recherche Scientifique, Université de Montpellier, Montpellier 34396, France
}

Programmed fork pausing is a complex process allowing cells to arrest replication forks at specific loci in a polar manner. Studies in budding yeast and other model organisms indicate that such replication fork barriers do not act as roadblocks passively impeding fork progression but rather elicit complex interactions between fork and barrier components. In this issue of Genes \& Development, Shyian and colleagues (pp. 87-98) show that in budding yeast, the fork protection complex Tof1-Csm3 interacts physically with DNA topoisomerase I (Top1) at replication forks through the C-terminal domain of Tof1. Fork pausing at the ribosomal DNA (rDNA) replication fork barrier (RFB) is impaired in the absence of Top1 or in a tof1 mutant that does not bind Top1, but the function of Top1 can be partially compensated for by Top2. Together, these data indicate that topoisomerases play an unexpected role in the regulation of programmed fork pausing in Saccharomyces cerevisiae.

The replication of eukaryotic genomes is a daunting task, involving the activation of thousands of origins from which replication forks progress bidirectionally until the completion of DNA synthesis. The nucleus is a crowded environment, and replication forks frequently pause when they encounter obstacles (Magdalou et al. 2014). Paused forks activate the DNA replication checkpoint to signal replication stress (RS) and are either rescued by converging forks or restarted by homologous recombination (Pasero and Vindigni 2017). Basically, replication forks can encounter two types of roadblocks. Unscheduled fork arrest can be caused by DNA lesions, proteinDNA cross-links, highly expressed genes, or structured DNA. This type of fork impediment has been implicated in genomic instability. In addition, programmed fork pausing has been reported at a variety of loci (Ivessa et al. 2003). Unlike accidental arrests, programmed pause sites induce fork arrest in a polar manner through an active process involving a cross-talk between the RFB and replisome components (Magdalou et al. 2014).

[Keywords: Tof1; Csm3; Mrc1; topoisomerase; Top1; Top2; RFB; replisome; replication fork pausing]

Corresponding author: philippe.pasero@igh.cnrs.fr

Article is online at http://www.genesdev.org/cgi/doi/10.1101/gad.335463. 119.
Programmed pause sites have been best characterized at the rDNA array and tRNA genes of the budding yeast Saccharomyces cerevisiae (Hizume and Araki 2019). Replication fork arrest at the rDNA RFB depends on Fob1, a protein that binds specific sequences downstream from the $35 \mathrm{~S}$ gene and blocks forks progressing in a head-on orientation relative to transcription (Kobayashi 2006). Remarkably, fork arrest at the rDNA RFB also depends on Tof1 and Csm3, two replisome components that form a complex with the checkpoint mediator Mrcl and are required for normal fork progression (Calzada et al. 2005). Fork progression through the rDNA RFB depends on Rrm3, a 5'-3' DNA helicase of the Pif1 family that removes Fob1 from the rDNA and other nonhistone protein barriers (Ivessa et al. 2003). Since the deletion of $R R M 3$ restores fork pausing in tof1 $\Delta$ mutants (Mohanty et al. 2006), it has been proposed that Tof 1 counteracts the "sweepase" activity of Rrm3 (Fig. 1A) through a process regulated by Cdc7 (Bastia et al. 2016). However, this rescue is only partial, suggesting that Tof 1 also controls fork arrest through a mechanism that is independent of Rrm3.

In this issue of Genes \& Development, Shyian et al. (2020) report the use of an unbiased forward genetic screen to identify novel factors acting with Tof1 to regulate fork pausing at the rDNA RFB. This so-called "cowcatcher" screen is based on the fact that fork stalling at the rDNA RFB affects the stability of ADE2 and URA3 markers inserted in the rDNA array. Using this approach, they identified TOP1 as one of the two genes increasing rDNA instability when mutated in tof $1 \Delta$ mutants. They also showed that Top1 interacts physically with the C-terminal part of Tof1 and is recruited to replication sites in a Tof1-dependent but Mrc1-independent manner. Interestingly, both Top1 and the C-terminal domain of Tof1 were required for pausing at the rDNA RFB and tRNA genes, supporting the view that Tof1 recruits Top1 to the replisome in order to promote fork arrest.

At first sight, the fact that Topl is required for stable fork pausing is intriguing, as Top1 normally promotes

(C) 2020 Larcher and Pasero This article is distributed exclusively by Cold Spring Harbor Laboratory Press for the first six months after the full-issue publication date (see http://genesdev.cshlp.org/site/misc/terms.xhtml). After six months, it is available under a Creative Commons License (Attribution-NonCommercial 4.0 International), as described at http://creativecommons.org/licenses/by-nc/4.0/. 

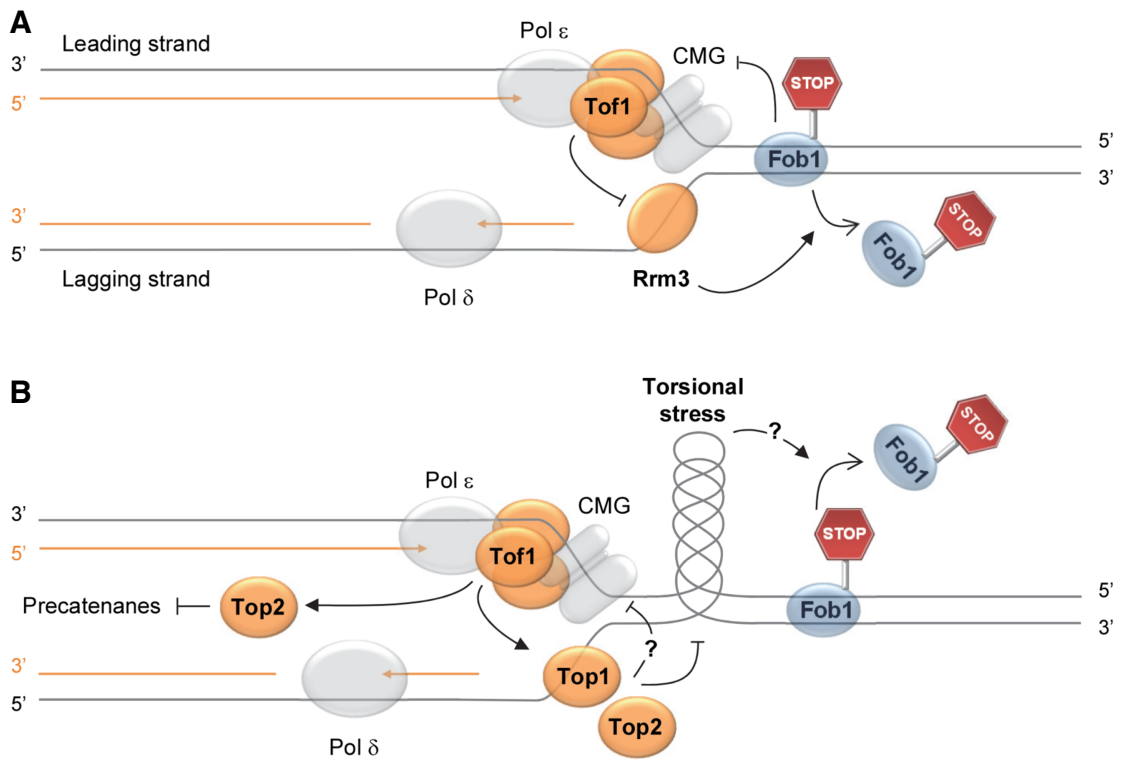

Figure 1. Mechanisms of programmed fork pausing at the rDNA RFB in budding yeast. (A) Replication fork pausing at the rDNA RFB depends on the Fob1 protein and on the Tof1-Csm3 complex, which interacts also with Mrcl (orange heterotrimeric complex). Fob1 can be displaced by the $5^{\prime}-3^{\prime}$ helicase Rrm3. In the classical "antisweepase" model, Tof1 prevents the sweepase activity of Rrm3 from displacing Fob1 from the RFB. $(B)$ In the novel sTOP model proposed by Shyian et al. (2020), Tof1 interacts physically with Top 1 and Top 2 to promote fork pausing. In the absence of Top1, the accumulation of positive supercoiling at the RFB could displace Fob1. Alternatively, the interaction between Tof 1 and Top1 could actively slow down the fork through a mechanism potentially involving Pol $\varepsilon$ and that remains to be characterized. It is worth noting that the antisweepase and sTOP mechanisms are not mutually exclusive and likely cooperate to regulate fork arrest at the rDNA RFB. fork progression by relaxing positive supercoiling in front of the replisome. One possible explanation for this requirement is that an excess of torsional stress may displace Fob1 when the fork reaches the RFB and therefore inactivates it (Fig. 1B). Alternatively, Tof1 may detect the presence of Top1 engaged on supercoiled DNA ahead of the fork and may slow down the fork by a mechanism that remains to be determined (Fig. 1B). It has been reported recently that the DNA polymerase $\varepsilon(\mathrm{Pol} \varepsilon)$ modulates the activity of the CMG helicase to promote fork arrest at the rDNA RFB in an in vitro assay (Hizume et al. 2018). Since Pol $\varepsilon$ was identified together with Top1 in the cowcatcher screen, it is tempting to speculate that Tof1 could sense the presence of Top1 on DNA with its C-terminal domain and slow down the replisome in a Pol $\varepsilon$-dependent manner. This interaction between Tof1 and Top 1 could also slow down forks encountering Top 1 cleavage complexes (Toplcc) trapped on DNA in the presence of the Top1 inhibitor camptothecin (CPT). This view is supported by the fact that both tof $1 \Delta$ cells and tof $1 \mathrm{mu}-$ tants lacking the $\mathrm{C}$-terminal domain that interacts with Top1 are hypersensitive to CPT.

Finally, the investigators reported that Tof1 also interacts physically and functionally with topoisomerase II (Top2), as this enzyme partially compensates for the loss of RFB activity in the absence of Top1. This observation is important as, unlike Top1, Top2 is also required for the decatenation of sister chromatids. Precatenanes accumulate when positive supercoiling is transferred behind the fork upon fork rotation. Interestingly, Tof1 also plays a key role at the replisome in preventing excessive fork rotation (Schalbetter et al. 2015). Altogether, these findings suggest the existence of a complex interplay between DNA Pol $\varepsilon$, the Tof1-Csm 3 complex, and topoisomerases in the regulation of programmed fork pausing. They also shed new light on the mechanisms by which DNA supercoiling may affect fork progression, arrest, and rotation.
Since the Tof1-Csm 3 complex is conserved in eukaryotic cells, it would be important to determine whether its human counterpart, TIMELESS-TIPIN, also acts with TOP1 to regulate fork pausing.

\section{Acknowledgments}

M.L. thanks Labex EpiGenMed for support. Work in the Pasero laboratory is supported by grants from the Agence Nationale pour la Recherche (ANR), the Institut National du Cancer (INCa), the Ligue Nationale Contre le Cancer (Équipe Labéllisée), and the Fondation MSDAvenir.

\section{References}

Bastia D, Srivastava P, Zaman S, Choudhury M, Mohanty BK, Bacal J, Langston LD, Pasero P, O'Donnell ME. 2016. Phosphorylation of CMG helicase and Tof1 is required for programmed fork arrest. Proc Natl Acad Sci 113: E3639-E3648. doi:10.1073/pnas.1607552113

Calzada A, Hodgson B, Kanemaki M, Bueno A, Labib K. 2005. Molecular anatomy and regulation of a stable replisome at a paused eukaryotic DNA replication fork. Genes Dev 19: 1905-1919. doi:10.1101/gad.337205

Hizume K, Araki H. 2019. Replication fork pausing at protein barriers on chromosomes. FEBS Lett 593: 1449-1458. doi:10 .1002/1873-3468.13481

Hizume K, Endo S, Muramatsu S, Kobayashi T, Araki H. 2018. DNA polymerase $\varepsilon$-dependent modulation of the pausing property of the CMG helicase at the barrier. Genes Dev 32: 1315-1320. doi:10.1101/gad.317073.118

Ivessa AS, Lenzmeier BA, Bessler JB, Goudsouzian LK, Schnakenberg SL, Zakian VA. 2003. The Saccharomyces cerevisiae helicase $\mathrm{Rrm} 3 \mathrm{p}$ facilitates replication past nonhistone proteinDNA complexes. Mol Cell 12: 1525-1536. doi:10.1016/ S1097-2765(03)00456-8 
Kobayashi T. 2006. Strategies to maintain the stability of the ribosomal RNA gene repeats. Genes Genet Syst 81: 155-161. doi:10.1266/ggs.81.155

Magdalou I, Lopez BS, Pasero P, Lambert SAE. 2014. The causes of replication stress and their consequences on genome stability and cell fate. Semin Cell Dev Biol 30: 154-164. doi:10.1016/j .semcdb.2014.04.035

Mohanty BK, Bairwa NK, Bastia D. 2006. The Tof1p-Csm3p protein complex counteracts the Rrm3p helicase to control replication termination of Saccharomyces cerevisiae. Proc Nat1 Acad Sci 103: 897-902. doi:10.1073/pnas.050654 0103
Pasero P, Vindigni A. 2017. Nucleases acting at stalled forks: how to reboot the replication program with a few shortcuts. Annu Rev Genet 51: 477-499. doi:10.1146/annurev-genet-120116024745

Schalbetter SA, Mansoubi S, Chambers AL, Downs JA, Baxter J. 2015. Fork rotation and DNA precatenation are restricted during DNA replication to prevent chromosomal instability. Proc Natl Acad Sci 112: E4565-E4570. doi:10.1073/pnas .1505356112

Shyian M, Albert B, Zupan AM, Ivanitsa V, Charbonnet G, Dilg D, Shore D. 2020. Fork pausing complex engages topoisomerases at the replisome. Genes Dev doi:10.1101/gad.331868.119 


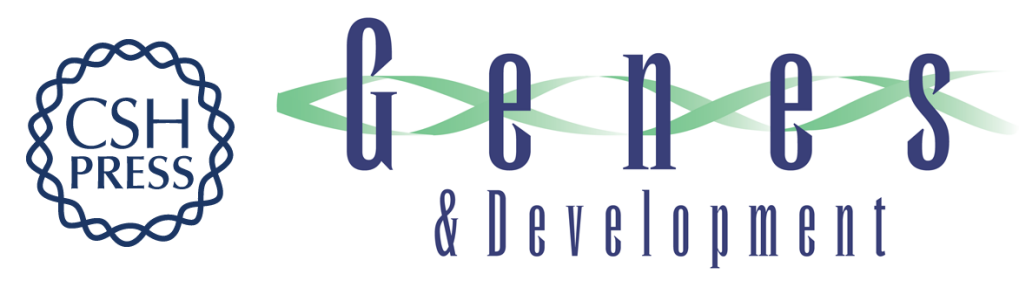

\section{Top1 and Top2 promote replication fork arrest at a programmed pause site}

Mélanie V. Larcher and Philippe Pasero

Genes Dev. 2020, 34:

Access the most recent version at doi:10.1101/gad.335463.119
Related Content Fork pausing complex engages topoisomerases at the replisome
Maksym Shyian, Benjamin Albert, Andreja Moset Zupan, et al.
Genes Dev. January, 2020 34: 87-98
References This article cites 11 articles, 6 of which can be accessed free at:
http://genesdev.cshlp.org/content/34/1-2/1.full.html\#ref-list-1
Articles cited in:
http://genesdev.cshlp.org/content/34/1-2/1.full.html\#related-urls
Creative This article is distributed exclusively by Cold Spring Harbor Laboratory Press for the first Commons six months after the full-issue publication date (see
License http://genesdev.cshlp.org/site/misc/terms.xhtml). After six months, it is available under a Creative Commons License (Attribution-NonCommercial 4.0 International), as described at http://creativecommons.org/licenses/by-nc/4.0/.
Email Alerting Receive free email alerts when new articles cite this article - sign up in the box at the top Service right corner of the article or click here.

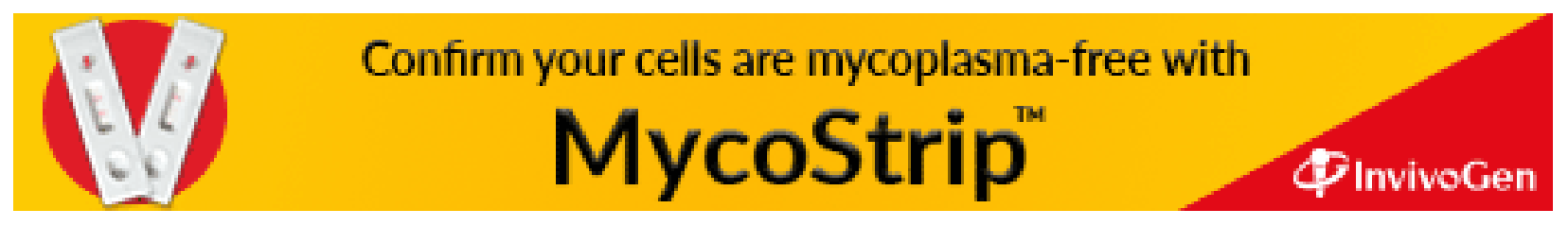

